\title{
Title: Reclaiming student voice(s): Constituted through process, or embedded in practice?
}

Abstract:

Removal of the student numbers cap, reductions in funding, and an accompanying need to generate revenue, has driven education towards neocapitalism and managerialism; students equate to income. An associated growth in performativity measures incorporates student voice as one of these benchmarking requirements. Aiming to explore and challenge assumptions about the role of student voice in post-compulsory education, this paper identified a missing viewpoint in the wider research; perceptions from those engaged in teacher education. This paper presents research undertaken with 24 participants (teacher educators, student teachers, and quality assurance managers) across 3 post-compulsory institutions in the UK. It explores perceptions about how student voice is espoused, enacted and experienced within the institutions, and whether this enables a democratic approach within education. The research considers questions raised about power, dialogue and engagement; and the impact of marketisation and consumerism on studentinstitutional relationships.

Keywords: student voice; consumerism; marketisation; power; teacher education; democracy. 


\section{Introduction}

'What the educator does in teaching is to make it possible for the students to become themselves.' (Horton and Freire, 1990, p. 181)

In order for a truly democratic approach to exist, there has to be a means through which individuals, who are committed to improving a culture and society, can work jointly to do so (Kitcher, 2009). Just over a century ago, Dewey (1916) invited us to consider what happens when relationships are not 'equitably balanced' and the aims of social groups are situated within externally-dictated process (Dewey, 1916). Focusing on one aspect where such joint working should exist, this research was predicated on a desire to explore - through dialogue with teacher educators, student teachers, and quality assurance managers - how they thought student voice was espoused, enacted and experienced within their settings (Bourdieu, 1977). Drawing on a constructivist approach, and an interpretivist theoretical perspective, the research posed a number of questions: why do we ask our students what they think; for whose benefit; and for what purpose (Hall, 2015, 2017)?

\section{Policy}

Starting in the early 1980s, we witnessed some 30 years of ongoing initiatives and policy drivers committed to democracy and education. Youth participation was encouraged (UNICEF, 1989) and mandated through various government directives (Department for Education and Skills [DfES], 2001; DfES, 2003; The Children Act, 2004; and The Education Act, 2002) that saw schools legally bound to commit to consultation with their students. Alongside this, similar legal obligations were established for all Further Education [FE] 
colleges to have a Learner Involvement Strategy that would be reviewed annually in discussion with students and their representatives (Foster Report, 2005). Government initiated a number of policies designed to improve the 'life chances' of post-compulsory students (DfES, 2005; DfES, 2006a; and DfES, 2006b) resulting in a Framework for Excellence (2007) and the Quality Improvement Agency's [QIA] (2008) focus on how to develop the 'expert learner'. Similar to the concepts underpinning the desire to embed a philosophy of dialogue and engagement (Hart, 1992), these political drivers also looked at ways in which to strengthen learner engagement and make it of value and meaning, with three strands of activity being identified. These focussed on a) personalisation strengthening learning and teaching by involving learners at an individual level; b) collective - engaging learners as 'representatives' of their fellow students (on student councils, course representatives, forum groups, etc); and c) organisation - considering how learners could be involved at various levels of decision-making so that a 'learner involvement culture' could become embedded within institutions.

Higher Education seemed to be following a similar track with the Department for Business Innovation and Skills [BIS] (2011), the Scottish Government (2011) and the Welsh Government (2013) all putting forth policy documents focusing on placing students 'at the heart' of the system. Schools were similarly urged to continue to identify 'how best to provide opportunities for pupils to be consulted on matters affecting them or contribute to decision-making in the school' (Department for Education [DfE], 2014). Yet in the midst of this emerged something else. The balance began to tip towards the 'efficiency' and 'effectiveness' end of the scale, and away from the 'learner-centred' and 'personalised' agenda (Fielding, 2006). What we are witnessing now in the UK, is not however an exclusive issue. Reaching back to the late decades of the 20th century the USA was already 
seeing the introduction of fees for its higher education students (J. A. Douglas, Douglas, McClelland \& Davies, 2015) and this marketisation of universities now also stretches across Australia and Canada (Collini, 2012).

\section{Assigning Value}

Within such an increasingly quasi-consumerist environment student satisfaction has attained 'commercial value' (Hillman, 2014); it is measured, and statements made in relation to student voice are informed by very specific contexts. Institutions are constrained to fulfil benchmarking requirements (National Student Survey; Key Information Statistics; the Teaching Excellence Framework, etc) through the outcomes of various key performance indicators. There is a danger that students may become regarded as 'active consumers but passive learners' (Ball, 2004, p. 10), so that the very processes of teaching and learning become valued more for their ability to contribute to the 'performance' of the institution, rather than recognising the intrinsic worth of the individual. The relationship between student and institution, and their 'connection' or 'role' in relation to student voice has thus begun to swing towards a transactional model (Tomlinson, 2017) with ever more consumerist language used in feedback mechanisms and the interpretation of that 'feedback' (Nixon, Scullion \& Hearn, 2018).

As a result of these changes over the last decade, student voice has become the object and focus of multiple points of externally-derived ambition: across compulsory and postcompulsory education; across the UK and globally. Certainly student voice has been allowed - and even enabled - but largely within the constraints and parameters established by institutions and policy (Canning, 2017). An unease has thus begun to develop amongst 
educators and students (Hall, 2015; 2017) about the underlying drivers and the rationale for asking students what they think. Assumptions are being made that all parties, or 'stakeholders' involved in these participatory mechanisms, have equal 'power', which they do not. If such 'engagement' is to be meaningful, there has to be shared trust and respect; shared power; shared risks; and shared learning (Cook-Sather, Bovill \& Felten, 2014, p. 6).

Building on previous work (Hall, 2017, p. 189) in addition to focusing on such processes, the aim of this research is to interpret 'voice' as it is situated in practices so that debate might be stimulated about how student voice could be used to invigorate new ways of thinking in teachers and students (Messiou \& Ainscow, 2015). For these two concepts to be able to attempt such a joint construction of knowledge however, the frames of reference - the boundaries of possibility - need to be established at the start to avoid a potential schism between the two perspectives (Bourke \& Loveridge, 2016; Groundwater-Smith \& Mockler, 2016). In this way we may find a way to 'reclaim' that original commitment to student voice(s) (Fielding, 2011a) and salvage this dialogue from being merely a 'tool to improve measurable outcomes' (Czerniawski, 2012, p. 17).

\section{Democracy}

Returning for a moment to the start of this 'student voice' era (1980s) it can be agreed that there was a general consensus that youth participation should be encouraged and that there should be ways in which 'voice' could be heard. At its essence, this was about establishing 'modes of sharing' (Bernstein as cited in Arnot and Reay, 2007, p. 318) and identifying how we might find ways in which to see 'learning through the learner's eyes' (Ramsden, 1998, p. 353). This was facilitated by policy drivers (UNICEF, 1989) and the United Nations 
Convention on the Rights of the Child, that sat alongside theoretical frameworks such as Hart's (1992) Ladder of Participation. Proposing stages through which levels of engagement could be increased, efforts were made to move from what could be regarded as purely manipulative and tokenistic at one end (Rudduck, 2006) to the potential for transformational connections and the development of agency at the other (Frost, 2008).

However, if we think of student voice as being something that pertains to a 'sociality of practice', then individuals are not only involved in a relevant activity, but accordingly 'exposed to the judgments and expectations of others' in relation to what is said (Volbers, 2012, p. 11). This 'involvement' may give rise to tensions between those 'subjects' and the environment within which they exist and interact. If we are viewing the concept of student voice therefore as something that is 'constituted through practice' and 'embedded in it', then we have to look at the procedures surrounding the concept of student voice. Instead of predefining - and then looking for 'evidence' of that voice - perhaps we would be better served if we first looked at those practices within which 'voice' is operative - or not (Volbers, 2012). If we want students to be 'active' in the construction of their lifeworld, rather than being 'trapped in the meanings, subjectives, and forms of authority determined by powerful others' (Lensmire, 1998, p. 268) we need to develop an approach that enables such opportunities and spaces to emerge. We also need to acknowledge that there are consequences for the ways in which 'power over and power with students' (Mayes et al., 2017, p. 15) is exercised within the notion of 'student voice'. For individuals this can have implications in relation to how they 'find' that voice and ability to speak; particularly difficult if you are part of a large school, college or university; but also if you are a part-time student, a work-based student, or an individual whose cultural background may make this difficult (Katsifli \& Green, 2010; Mariskind, 2013; Rudduck \& Fielding, 2006). Other 
influences may also impact on any such dialogic encounters, not least the existence of a 'power relationship' between the 'speaker' and the 'listener' (Starhawk, 1988; Taylor \& Sutton, 2016). Acknowledging that such encounters have potential to shape both the 'teaching' and the 'teachers' (Mariskind, 2013), importance must be given to issues surrounding this potential power balance, or imbalance, within the classroom so that safe spaces can be established for all parties.

Yet in framing our contexts and expectations, we have to exercise caution. Too often, our 'search for authenticity as an objective notion masks how power relations operate in producing what counts as student voice' (Nelson, 2015, no page number). Although the context is one of middle-grade students set in New Zealand, this study resonates with the research within this paper. Aiming to 'open up student influence' and explore ways in which to 'collapse the student/teacher hierarchy' (Nelson, 2015, no page number) it was anticipated that students would welcome opportunities to work alongside teachers and participate in decision-making. In reality, students established their own collaborative emphasis by working with their peers to create 'student-student' influence instead. Perhaps this makes us guilty of trying to define what counts as authenticity for students, and of having the viewpoint that all will be well if we just 'get student positioning 'right' or if we get our methods 'right', freeing the voicing process from restraints' (Nelson, 2015, no page number). We cannot, therefore, lose sight of the implications of power, either as 'overt' or 'hidden' within hierarchical and institutional relationships (Robinson \& Taylor, 2013) and must continue to create spaces and opportunities for 'encounters' if we are not to fail the tradition of democracy (Fielding, 2010).

\section{Performativity}


What then, can be agreed upon? Well, perhaps there can be agreement that 'student voice' is accorded importance; and also, that the 'act of listening' to students exists. However, we may not agree about the purpose(s) for which this is done, nor the rationale behind the ‘judgement(s)’ made (Tedder, Jones \& Mauger, 2008). In attempting to engage with students, policy drivers are impacting on the potential for 'student-centred democratic education, engagement and the liberation of voice' (Seale, Gibson, Haynes \& Potter, 2015, p. 547). This recent research considers the nature of potential partnerships between staff and students, in particular around issues of 'resistance' and 'power', and again it has highlighted concerns about how we conceptualise student voice.

There is an increasing 'brokerage' of education that may be impacting on students' identity positions and their 'wider sense of what it means to be a student' (Tomlinson, 2017, p. 455). Alongside this, we also see a reciprocal impact on teachers' identity positions as they are deemed responsible for ensuring the quality of the student's teaching and learning experience. Almost perversely, 'student performativity' therefore becomes equated to, and viewed as, 'the mirror image of teacher performativity' (Macfarlane, 2015, p. 338). Against this shifting focus of institutional engagement with students, we are also now beginning to witness a reciprocated move within the student body whereby students question the quality of their university experience, not purely in relation to the teaching and learning, but with attention becoming focussed on whether it represents 'value-for-money' (Williams, 2012). This may be as a result of students entering this post-compulsory environment with 'little awareness of alternative roles available for them as students' (Nixon et al., 2018, p. 928). It may also, however, be influenced by the grafting on of a commercialised framework, through the Competition and Markets Authority (CMA). The associated impact of this on an educational context is to threaten the pedagogic relationship between students and teaching 
staff. If students are 'encouraged to view themselves as consumers, they are more likely to view the act of learning as a commercial transaction' (Naidoo \& Jamieson, 2005, p. 272). The transaction therefore becomes one whereby teachers, on behalf of the institution, become the conduit through which knowledge is transferred to the purchaser of that commodity - the student (Tomlinson, 2017). It is not surprising, therefore, that the relationship between students and their educational institution has changed. Having surveyed undergraduates about their consumer attitudes in relation to their post-compulsory education experiences and identities, attention is focused on concepts whereby institutions inadvertently establish a view of 'education as an exchange of money for services' (Bunce, Baird \& Jones, 2016, p. 16). Institutions need to consider how the roles and identities of students and teachers are interconnected, not through measures of 'performativity' but through opportunities for developing students as proactive enquirers and contributors to their teaching and learning (Dickerson, Jarvis \& Stockwell, 2016). Otherwise we are in danger of having student voice 'constituted through process' rather than 'embedded in practice' and it is this

\footnotetext{
'....governmentality of voice... [that rather than being]... a means to monitor the effectiveness of teaching in schools... [by]... supporting student and teacher learning through reflection... [...]...becomes a mechanism for organisational surveillance and discursive power.' (Charteris \& Smardon, 2019, p. 97)
}

Ultimately, this may lead to us stepping off the precipice into a consumer-ranking TripAdvisor ${ }^{\mathrm{TM}}$ style model of student voice that stipulates where, when, and how the student voice is heard and the purpose to which that 'voice' is put (Canning, 2017). However, to apply such a reductive approach to something that is far from simple is to ignore how 
individuals and groups internalise their thoughts, beliefs and values; their interactions with the environment and social structures with which they co-exist (Bourdieu, 1977).

\section{Methodology and Methods}

'Who speaks and under what conditions he speaks: this is what determines the word's actual meaning.' (Bakhtin, 1981, p. 401)

Recognising that we must start 'where the learner is' (Bruner, 1977, p. xi) the intent has been to build on earlier work (Hall, 2015; 2017) to explore what student voice might mean from an individual's perspective across diverse roles, environments and curriculum settings. As the study was designed to enable perspectives to be drawn from a range of individuals, it took an abductive discovery approach to ensure that 'the researcher grounds a theoretical understanding of the contexts and people he or she is studying in the language, meanings, and perspectives that form their worldview' (Bryman, 2012, p. 401). The study thus engaged with participants from different institutions who had either responsibility for initial teacher education (ITE), were a student teacher, or were a member of an institution's quality assurance teams. Student teachers came from assorted contexts in terms of curriculum areas (academic, vocational, work-based, and training providers) and settings. The work has drawn on a constructivist approach, using an interpretivist theoretical perspective and a qualitative methodology that used interviews and small group discussions.

Having secured ethical approval from the University of Wolverhampton, and employing a purposive approach, teacher education staff were contacted in three post-compulsory institutions. Individuals were provided with an overview of the research, participant 
information and consent forms, and invited to distribute these amongst their student teachers and quality assurance managers so that individuals could then self-identify to be participants in the study. In total there were 24 participants, drawn from these 3 FE Colleges delivering (HE in FE) initial teacher education programmes, across the Midlands and North West of the UK. From the 3 ITE institutions, participants comprised of 5 Teacher Educators, 17 Student Teachers, and 2 Quality Assurance Managers (with responsibility for overseeing HE in FE provision); all participants were interviewed either as individuals or within small groups.

All interviews were recorded on a password secured digital voice recorder and later analysed for themes and insights emerging from individual perspectives and then reviewed for recurrent themes and analysed for the way language was used to ascribe meaning within responses to the questions posed.

\section{The Participants}

'When educators and educators-to-be learn to listen to students, they can lead the way for others to change.' (Cook-Sather, 2002, p. 10)

In exploring perceptions of how student voice in post-compulsory education is espoused, enacted and experienced through a number of lenses (Teacher Educators, Student Teachers and Quality Assurance Managers), the aim of this research has been to consider how these personal, interpersonal and institutional viewpoints could be brought together to form a more coherent 'whole'. To fulfil these aspects the different groups of participants were asked slightly different questions. 
Focusing on the Teacher Educators first, these were asked the following:

- When you think about student voice, how do you feel this relates to your role as a teacher educator?

- How do you think your student teachers perceive themselves in relation to student voice?

- How is student voice viewed by your institution?

- What informal opportunities are there to enable student voice?

- How do you feel these compare to more formal opportunities?

- What impact do you feel student voice has on a) you, b) the students, and c) the institution?

- If you could do something different, or improve it in some way, what would you do to change the way that students can 'have a voice'?

Student Teachers were asked slightly different questions as they were able to contribute from two perspectives - that of being a student and also a teacher:

- What do you feel is your role in relation to student voice when you are in your Initial Teacher Education classes?

- How is similar to, or different from, when you are back in your own classrooms and teaching?

- How do you feel your learners 'experience' student voice?

- What makes you think this?

- What informal opportunities are there to enable student voice?

- How do you feel these compare to more formal opportunities? 
- What impact do you feel student voice has on a) you, b) the students, and c) the institution?

- If you could do something different, or improve it in some way, what would you do to change the way that students can 'have a voice'?

As the two Quality Assurance Managers participated from an institutional perspective, and this was a 'pair' interview format, the decision was made to adopt a looser, more conversational style to maximise the potential for concepts to emerge out of the data collection (Bryman, 2012). This enabled them to articulate their views on student voice as it was espoused and enacted within their institution, their perceptions of the impact this had, potential barriers, and the ways in which they were involved with this. However, to ensure a transparent approach, and to enable these two participants to remain 'connected' to the wider questions being asked, they were provided beforehand with copies of the questions being discussed with the Teachers and Student Teachers. For these Quality Assurance Managers, there was a strategic awareness of how student voice was viewed by their institutions and consideration of some of the implications of formal and informal opportunities. They highlighted some of the frustrations felt, but there was a real commitment to find ways to 'close the loop' (Powney \& Hall, 1998).

Across the participants, Teacher Educators had an interesting relationship to the research as their students were also teachers. As such, Teacher Educators reflected on their relationships with their own students; but they also engaged in conversations with these Student Teachers about their respective learners - so the breadth and scope of the dialogue spread across multiple layers and perspectives. 
The Student Teachers, much closer to the wider student population, expressed concerns about the 'quality logics' and the ways in which 'scores are endlessly sought, captured, codified and used to assist staff performance management' (Nixon et al., 2018, p. 929). What they sought, was much more of a collaborative partnership approach and informal opportunities for exchanges of dialogue between students and teachers.

\section{Results and Discussion}

'...structures don't have voices—-people do.'

(Porter, 2008, no page number)

The research was interested in finding out what contributed to, and influenced, a participant's perception(s) and perspectives in relation to 'student voice' and how this is espoused, enacted and experienced within their institution. Through their individual narratives the aim was to explore how these conversations might provide insights into ways of developing greater potential for engagement (Hall, 2017), thus enabling learners 'individually and collectively, to contribute in a new way' (Hall, 2017, p. 188) to the concept of 'student voice'.

As the various conversations were analysed the following main themes emerged - to different extents - across the participant groupings: power; marketisation; consumerism; and dialogue and engagement. In considering extracts from the participant responses, the results are integrated, and presented, within these overarching headings. Where comments are attributable to a specific participant, this is indicated by appropriate coding (for example T1, T2, for Teacher Educators; ST1, ST2, etc for Student Teachers; and QA1, QA2 for Quality Assurance Managers). 
In analysing the data, responses varied from a sentence or two, to longer answers; some of the responses were too broad to be coded to a specific theme, or isolated responses not observed elsewhere in the data. Therefore out of the entirety of the interviews and discussions there were a total of 129 'complete' responses, with 100 of these that could be attributed to a specific thematic code: power; marketisation; consumerism; and dialogue and engagement. Within the discussions there was also a sub-theme of accountability of students in relation to their responsibilities when involved with student voice mechanisms. This is noted in Table 1 but was too embedded within the responses and threaded through the other themes to extract as a more definitive set of data. The following table presents a breakdown of the coding by participant category and theme.

Table 1: Number of responses from participants attributed to identified thematic coding

\begin{tabular}{|c|c|c|c|c|c|c|}
\hline & & \multicolumn{4}{|c|}{ Thematic Code Assigned to Response } & Sub-theme \\
\hline \multirow[t]{2}{*}{$\begin{array}{l}\text { Participant } \\
\text { Category }\end{array}$} & \multirow{2}{*}{$\begin{array}{l}\text { (Total } \\
\text { number of } \\
\text { responses) } \\
\text { Number } \\
\text { identified } \\
\text { for firm } \\
\text { coding }\end{array}$} & Power & Marketisation & Consumerism & $\begin{array}{l}\text { Dialogue \& } \\
\text { Engagement }\end{array}$ & $\begin{array}{l}\text { Accountability of } \\
\text { Students }\end{array}$ \\
\hline & & $\begin{array}{l}\text { Coded } \\
\text { responses } \\
(\%)\end{array}$ & $\begin{array}{l}\text { Coded } \\
\text { responses }(\%)\end{array}$ & $\begin{array}{l}\text { Coded } \\
\text { responses }(\%)\end{array}$ & $\begin{array}{l}\text { Coded } \\
\text { responses } \\
(\%)\end{array}$ & $\begin{array}{l}\text { Coded responses } \\
(\%)\end{array}$ \\
\hline $\begin{array}{l}\text { Teacher } \\
\text { Educator }\end{array}$ & $(50) 46$ & $\begin{array}{l}16 \\
(34.78)\end{array}$ & $8(17.39)$ & $5(10.87)$ & $17(36.96)$ & $7(15.22)$ \\
\hline $\begin{array}{l}\text { Student } \\
\text { Teacher }\end{array}$ & (53) 34 & $8(23.53)$ & $5(14.71)$ & $5(14.71)$ & $16(47.06)$ & $5(14.71)$ \\
\hline $\begin{array}{l}\text { Quality } \\
\text { Assurance } \\
\text { Manager }\end{array}$ & (26) 20 & $7(35.00)$ & $3(15.00)$ & $5(25.00)$ & $5(25.00)$ & $1(5.00)$ \\
\hline Totals & (129) 100 & 31 & 16 & 15 & 38 & 13 \\
\hline
\end{tabular}

It can be seen that there was a definite weighting in the data, with the overall majority of the 100 coded responses (38\%) focusing around the theme of dialogue and engagement. Alongside this, power was also an important aspect in the discussions, with $31 \%$ of the overall responses. Although recognised as key influences, marketisation (16\%) and consumerism $(15 \%)$ were substantially less within the overall responses. These two thematic 
categories could have been dealt with jointly but the nuances in the responses would have been lost. Participants considered marketisation to be driven more from the perspective of the institution, whereas consumerism was perceived to be from the standpoint of student interaction with the institution and their educational experience. Within the dialogue the subtheme of accountability represented $13 \%$ of the coded responses, primarily from the Teacher Educators and the Student Teachers; this was however integrated within the two other main themes of power and dialogue and engagement and as such it is not discussed in a separate section, but included as appropriate within the discussion of the data. These aspects are explored in more detail in the following thematic analysis and discussion.

\section{Power}

There are three fundamental concepts of power that emerged from within the discussions: 'power over' such as that based within the hierarchical relationships of student and teacher; 'power-from-within' that considers how we connect with our environment and others, including the ways in which this can influence our sense of agency; and 'power with' that emerges when there is a relationship built on equality and 'shared influence' (Nelson, 2015; Starhawk, 1988). Each of these could be considered as either 'overt' domination - existing by virtue of established hierarchical status; or 'hidden' domination - apparent through perceived hierarchical positioning (Robinson \& Taylor, 2013, pp. 38-39).

Initially there was an expectation that 'power over' would be demonstrated from a traditional viewpoint of the student-teacher relationship, with 'power' residing with the teacher. However, when the data were analysed a degree of anxiety was very much present, with Teacher Educator participants using such words as 'fear' of student voice being used 
'against' staff, and that the focus was not on the education element of a student's experience, but more on the language of business and customer satisfaction. They felt that the emphasis was on how they were able to contribute towards measurable outcomes that could be seen to deliver value-for-money. We know that students are 'routinely encouraged to rate the quality of their provision under the remit of increased student voice' (Tomlinson, 2017, p. 451), and in responding to these issues around power (Starhawk, 1988) we need to consider therefore what is influencing the various elements of student-teacher, student-institution, and teacherinstitution relationships; and what is happening within these interactions.

Within the conversations, participants spoke about being 'taught as teachers to fear student voice' as it being there to provide negative points to be 'held against you' (T1). Teacher Educators spoke of student voice sometimes being seen as 'more important than the teacher voice' (T2); and from a Student Teacher that there was

‘...a power..... an influence with student voice' (ST15)

A disconnect was evident between the desire to involve and engage with students, encouraging them to contribute feedback and demonstrate that aspect of 'power with', and the tensions that can arise. Although we may anticipate that power is not static, and that an 'unsettling' of existing power relationships would be a means through which to challenge and transform institutional hierarchies (Foucault, 1980), within the research there were genuine concerns from Teacher Educators and Student Teachers about the balance of power being more with the students than the teachers. Similar concerns have been raised in research in the USA, Australia and the UK (Bahou, 2011) for some time about the degree of 'worth' attributed to the voice of the student over the voice of the teacher. These aspects could be 
seen within the issues raised by Teachers, Student Teachers, but also from the Quality Assurance Managers who acknowledged that there were concerns in terms of how the teaching staff engaged with student voice mechanisms. They spoke about the:

'Need to get staff 'buy-in' to the importance of learner voice.' (QA1)

'Staff say things like, "I love my teaching, but I can’t be doing with all this.” (QA1)

This was not a flippant response however to chasing quality assurance measures, there was a genuine commitment here to create 'an environment for meaningful engagement between students and staff' (Carey, 2013, p. 1290). They did not want the feedback to be mechanistic, but to ensure that the feedback got 'back to the learners' (QA2) so that there could be a sense of relationships built on equality and shared influence: power with (Starhawk, 1988).

As participants talked, it was interesting to hear from a number of Student Teachers who spoke of the difference when Student Representatives were involved in feedback in more formal settings. Particularly where these were chaired by someone not known to them. It was felt that these contexts were taken more seriously and that it:

'.......made them think about what they're saying....maybe it isn't such a big issue. Maybe it's something that's the student's responsibility.' (ST group response)

This aspect of 'accountability', of the power-from-within that can arise from an individual's interactions with their environment, and the associated potential for sense of agency to be developed or squandered, was evident within the dialogue. There was a feeling that when 
students can engage in anonymous surveys they can use these as a 'platform to complain about everything' (ST6); from the food in the canteen to campus parking, asking for 'things that aren't possible' (QA1). That long-held grudges can be played out (ST16), and that such formats can provide an 'opportunity to say things they would never say to somebody's face' (T2). Teacher Educators talked about students being 'much more in control than the organisation and the teacher' (T2) and of failing to understand the 'impact of the responses they give and how it reflects in the benchmarking aspects' (T5).

Despite some of the reservations and difficulties acknowledged however, Teacher Educators were committed to providing a 'safe space' for student voice - with their own student teachers. They reminded them to be 'productive with your voice' (T1) and to constantly reflect; to consider their students' perspectives, and to ask themselves how they think their students might feel about something they have experienced within the teaching and learning environment (T3). After all, we know that there is a need to be mindful of the fact that the learning setting - the pedagogy in practice - may not accurately reflect the variance that exists between what we think we have done in class, what we actually did, and how the students experienced it: the difference between the espoused, enacted and experienced (Bourdieu, 1977).

We give them [student teachers] that space in our courses to have a voice and explore ideas in a safe environment. (T2)

Within the conversations there was apprehension that knowledge was being 'reconfigured as a commodity to be purchased....[with teachers acting as]...information brokers' (Tomlinson, 2017, pp. 453-454). Participants felt that the resultant focus was entirely on measurable 
outcomes that could be seen to deliver value-for-money and within the conversations, participants expressed genuine anxiety. What becomes apparent from the data therefore is a need always to have at the forefront of our interactions the knowledge and awareness that when processes are externally-dictated (Dewey, 1916), as with many student voice mechanisms and processes, endeavours have to made to ensure that relationships exist that can maintain the ability to be 'equitably balanced'.

\section{Marketisation}

There is undoubtedly strong competition for students, with promotional activities targeted at a specific market (Nixon et al., 2018, p. 929). Having an 'education' is regarded almost in the same ways that a 'return on investment' is in a business context - something with potential future value (Tomlinson, 2017). If we are honest, this has probably always been there to an extent, but perhaps we now see this weighted more in terms of evidencing 'value for money', rather than education-for-education's sake. For institutions that have become 'marketised' the critical outcome is on the 'service offering' (Nixon et al., 2018, p. 928) and the degree of student 'satisfaction' or 'dissatisfaction'. Something our Teacher Educators relayed was their sense of disappointment at the degree of data-chasing and the ways in which this 'customer' information was driven to the foreground. Student voice was regarded largely as an 'instrumental undertaking orientated towards increased measurable, organisational performance' (Fielding, 2010, p. 66); essentially using student voice to fulfil the needs of the institution and external bodies.

There was a sense of a 'shifting' of students' expectations in this marketised environment and accordingly a commensurate change in 'how students perceive their relationships to their 
institutions' Tomlinson, 2017, p. 451), including seeing themselves as 'consumers' . Perhaps institutions are guilty of contributing to this by the ways in which they present 'those lovely posters on the wall....97\% of students are happy with their course, $95 \%$ of students would recommend...' (T2). Driving this underlying, constant 'push' and pressure from institutions to have the required number of responses from surveys in order to be 'counted' in the data staff talked of their concerns and anxieties relating to the "figure-chasing.....so much pressure to get figures through' (ST4). Participants reflected on the 'need for data' being what drove the need to survey so that institutions could publish the 'satisfaction rates on the back of the bus.' (T1)

We know, however, that when a student voice agenda is introduced, there can be a desire from institutions to look for 'quick wins' and those areas where changes can be made with a degree of ease. Where it becomes more difficult is where student feedback is challenging (Bourke and Loveridge, 2016) and there is a danger that institutions will use it for 'their own means, not actually using it to enhance the experience'. (T3) Where participants did see potential for 'different' outcomes was when there are opportunities for more informal exchanges. If we can find ways to create spaces for such 'restless encounters' then we may be able to extend the 'possibility of not only retaining but extending this radical openness, provisionality and reciprocity' (Fielding, 2010, p. 67).

Whilst there were doubts expressed in terms of 'what' data and comments were actually used in promotional materials, and a degree of cynicism in the ways these were used, there was a strong desire to remove the formalised student feedback processes: 
'It's interesting... when you speak to the students you teach, or in the corridor, the feedback you hear is not the feedback that you see around the institution.' (T4)

There is great potential to be had in maintaining a more open, and constant, dialogue with students (Katsifli \& Green, 2010), enabling greater understanding to develop from face-toface conversations and providing opportunities to clarify the 'intent' underlying comments made by students; returning to the issue of accountability.

Perhaps one of the most telling of comments that will resonate with many came from one of the Quality Assurance Managers recounting a conversation had with an ex-Principal some time previously (thus echoing the shift that has taken place over recent years):

'Talking to XX a few years ago who said 'It's education. It shouldn't be a business, it's education, we just need to be more business-like." But I think the shift's gone further, we're not now business-like, we are a business and for a teacher at heart, that's quite sad.' (QA2)

Questions arise, therefore, in relation to how we enable or inhibit partnership, how we listen to, and learn from, each other. With so many of the developments in the arena of student voice being dominated by a neo-liberal approach embodied in a consumerist viewpoint, we must not lose sight of the person as 'relational' to others, not as a self-sufficient 'individual' (Fielding, 2011b). There is scope for greater development of pedagogical partnerships that may yet challenge that viewpoint of students in post-compulsory education as customers, and 'consumers' of education (Matthew et al., 2019). 


\section{Consumerism}

At strategic level, conversations around institutions are influenced by a need to ensure compliance with consumer regulations (CMA), enshrining 'the satisfaction of the sovereign student as a legitimate and central imperative of the HEI' (Nixon et al., 2018, p. 929). This was evident in the feedback from participants, including the language that they used, talking of 'customer', 'service', 'complaints' and 'rating'.

In today's market-driven economy, it would not be unreasonable therefore to say that students' perceptions of their relationship to their institution have shifted (Tomlinson, 2017). Participants talked about how students are asked to rate 'things all the time, but maybe when they choose to, not when they're told to' (T5). This point was interesting in that it highlighted the move towards a consumerist approach - and of students being used to providing feedback on companies and experiences; but in a non-educational context (T2). However, if institutions make the student the 'customer', and education the product - by default including their 'service experiences' of teaching and learning within that 'product' then are we not forcing them towards a relationship in which the 'customer is always right' (T5)? From an institutional perspective, therefore, these student 'narratives' are being used to understand 'what drives satisfaction and dissatisfaction' (Douglas et al., 2015, p. 330): a consumerist approach towards student feedback. Embedded within the participant conversations were comments about the ways in which institutions approach the national student surveys:

'The NSS! Training students around the questions, making everything explicit. Letting students know what the rules are.' (ST14) 
Yet we should not forget that when students are motivated to engage with their own education, then educational practice can be improved, and as teachers who 'listen to and learn from students' we gain a fresh perspective on what is happening in our classrooms (CookSather, 2002, p.3). However, Student Teacher participants expressed concerns that some students remain at the 'marginalia' (Higgs, 2016), whilst the voices of 'others' were the ones always heard: the confident, the articulate, those with a strong sense of self-efficacy and identity (Hall, 2015, p. 122). If we are to have a critical pedagogy, then we need to have ways in which to provide access to all voices; otherwise we risk failing to redistribute power 'not only within the classroom, between teacher and students, but in society at large' (CookSather, 2002, p. 10).

\section{Dialogue and engagement}

At the crux of this discussion, and the research, we need to consider a fundamental Bakhtinian question that encourages us to reflect on 'Who is doing the talking? [so that it] can be [re]formulated in terms of 'Who owns the meaning?', Holquist (as cited in Wertsch, 2005, p. 222). Yet in doing so, we also need to address some of the points raised by Teacher Educators in terms of 'what' we are asking students to do: to reflect on, and answer questions about, their learning experience. As one noted, 'we don't teach these skills' (T3) so how can we be confident that they 'really know what they're actually answering?' (T4) If we want our students to develop democracy, agency, reflexivity - and accountability - then as educators we need to consider how this can be facilitated so that they acquire skills that have the potential to be transferable into their wider lives (Bron, Bovill, van Vliet \& Veugelers, 2016; Cook-Sather, 2002; Horton \& Freire, 1990). Surely this must be an important point for us all to consider. Within any dialogic encounter, there is a power relationship between the 
'speaker' and the 'listener' (Taylor \& Sutton, 2016) regardless of the format within which this exists. In truth, it is often weighted even further when the 'speaking' exists through the medium of the written word; but we know that sometimes this can be 'counter' to the perceived hierarchical relationship between student and teacher. Remember the concerns expressed about surveys providing an opportunity for students to say things they 'would never say to somebody's face' (T2). What should also not be forgotten within all of these discussions is what happens when students are 'unable' to engage with the standardised feedback formats. When there are '...less able students, they've never been able to sit round the table and have their voice heard.' (ST8)

Although there were doubts about the rhetoric and policy drivers surrounding student voice 'mechanisms', there was a real commitment to talk about how conversations and dialogue related to teaching and learning could be 'shaped by and in turn shape[s] professional practice' (Higgs, 2016, p. 48). All participants recognised the value in having much more informal ways - and regular opportunities - to enable students to engage in regular discussions that individuals could see related to their situation and whereby there was a 'direct response' that actually related to 'the teaching and learning environment' (ST1). This was not necessarily to say that such dialogue had to occur within the classroom; there was enthusiasm for doing this 'outside of the environment they're in with the teacher because it's a different response than when they're in class' (QA1). Yet participants spoke about the 'institutional' relationship between 'speaker' and 'listener' sometimes impeding potential communication conduits and it was noted that there was a danger of students only, in effect, being 'consulted on decisions that have already been made, as opposed to being involved in making these decisions' (Carey, 2013, p. 1291). Student Teachers reported that students 'sometimes feel it doesn't make a difference what they say. It's a case of just "hammer them 
through" the surveys' (ST15), and of students not actually knowing what happens to the feedback they have given (ST16).

So we reach a crossroads. We know that it is essential that students have opportunities to understand and assess their own learning (Cook-Sather, 2002), but there needs to be greater flexibility in how feedback is obtained and the questions asked. Why can we not be more creative, rather than 'pigeon-hole everybody into the same questions' (ST4)? The reality behind this uniform survey approach is, of course, the need to ensure a 'measure' that can be benchmarked and contribute to national league tables in order to meet those externally-driven process requirements; but can there not be something else? This challenge was considered by one of the Teacher Educators who wanted to give learners more 'input in the design of tools and mechanisms that we use for learner voice' (T5), noting that it should not just be about what we, or the institution, tell them to do; or how to do it.

In the interviews there was also an underlying desire to do 'something meaningful' with the feedback, to 'close the loop’ (Powney \& Hall, 1998). Quality Assurance Managers talked about doing something 'different' and of finding spaces that were 'outside of the environment' in which students were used to having these sorts of conversations. This was also discussed by Student Teachers in terms of looking for 'informal feedback opportunities' - particularly those where there was a 'direct response within the teaching and learning environment'.

When we become teachers, and teacher educators, our journey starts from a place where we are asked to develop our concepts of 'educational philosophy'; our beliefs in terms of how our students learn best; our role(s) in the classroom, institution and wider society - to enable 
and nurture a democratic and rights-based approach to education (Messiou \& Ainscow, 2015). We need to continue to strive for ways to encourage our students to engage in dialogue and discussion, with each other, their teachers, and the subject of their learning; to develop their identity and agency, but also to acknowledge their accountability.

\section{Conclusion}

'Listening and learning from student voices necessitated a shift from the ways in which teachers engaged with students and how they perceived their own practices.'

(Bahou, 2011, p. 4)

This research was predicated on a desire to explore - through dialogue with teacher educators, student teachers, and quality assurance managers - how they thought student voice was espoused, enacted and experienced within their settings (Bourdieu, 1977). Building on earlier studies (Hall, 2015, 2017) this was a small-scale research project working with 24 participants. As such, although confined to this specific sectoral context, it did provide a representation of views across three FE Colleges delivering ITE programmes in the Midlands and North West of the UK, and as such begins to open out the debate in relation to teacher education and student voice. The research provided opportunities to talk to participants who could respond to the questions through different lenses and perspectives; and their frustrations with the 'processes' were evident. Set formats and repeated use of the same mechanisms have almost become like 'learned behaviours' that are 'done to' both students and teachers alike (Nelson, 2015). The posters, marketing quotes and survey data, do not reflect what students tell their teachers 'on the ground' in more informal settings where a more conversational approach is used; but this is the dominant and 'espoused' storying of 
student voice. If we are to consider options centred on a variety of knowledge interests and their 'interaction with system worlds and lifeworlds' then student voice has to become something that is evaluated by means other than the extent to which it serves 'instrumental purposes' (Mayes, et al., 2017).

Constraints and tensions thus emerged: institutions have to be able to provide evidence of students having a 'good experience' that provides 'value-for-money' (Tomlinson, 2017); where legitimacy is created through meeting, and enhancing, organisational ends (Fielding, 2010). Failure to do so may have a detrimental influence on the ability of that institution to recruit students and that ultimately will impact on staff employment and development of institutional resources. This is the harsh reality of that 'business' world alluded to by one of our Quality Assurance Managers. However, the disillusionment, and dissatisfaction, within the comments from the participants is at heart, sad and speaks to a need to find fresh approaches to learning and new 'notions of power' (Bovill, Cook-Sather \& Felten, 2011). In response to the overarching questions of this research - do we find student voice(s) constituted through process, or embedded in practice - participants advocated a desire not to see student voice as a reified thing to be measured (Czerniawski, 2012; Hall, 2015, 2017), but rather as an interconnecting, overlapping concept that is embedded in context; in our practice(s) as teachers and educators. It was also about finding ways of cultivating an institutional and political culture within which teachers no longer have a perception that the 'influence' of the student voice is leading to an environment in which it is to be feared, not welcomed. So the focus becomes about negotiating - or re-negotiating - power; of valuing partnerships that are co-constructed and not imposed. Teachers, students and institutions have to be honest about where power imbalances lie, and of the attitudes that underpin them in individuals, within institutions, and ourselves as researchers. 
We have to challenge the 'cultural norms' and 'modes of authority' that 'infuse' teacherstudent relationships (Robinson \& Taylor, 2013, p. 39). In this way, we arrive at a set of questions to take forward into new research. How do we expand existing opportunities to be accessible to more individuals? Where are those spaces within which we can create environments for 'different' types of dialogue and conversation; the 'restless encounters' (Fielding, 2010)? How do we enable students to acquire the skills necessary to engage with such conversations - the democracy within education? The participants talked about students now having these skills, so we need to find the means to develop this reflexivity within our learners. Then we can open up a means through which they can develop 'confidence and power' and 'be in control of their own knowing' (Mayes, 2017, p. 14). Power becomes shared; students have potential to practise democratic skills; and we acknowledge the unique perspectives that their contributions can have when we no longer constrict or confine what 'counts' as authentic student voice (Nelson, 2015).

In terms of next stages, therefore, taking these questions out to further participants engaged in teacher education in other FE contexts would help to corroborate the findings, and/or identify new themes. Widening this remit to include teacher educators who work within a purely HE setting, would enable a comparison of views within the same curriculum setting, but operating in a different, although aligned, post-compulsory sector. Such research would then evaluate the implications of policy changes being witnessed in HE in relation to the 'role' of student voice in a changing environment: NSS, rate your module, rate your tutor (!) and the TEF. A further development would then be to consult with students in an attempt to disrupt or contradict previous ways of understanding, and to co-produce a new 'conceptual gateway' (Cook-Sather \& Luz, 2015, p. 1098). 
If we can seek these new possibilities, then as we extend our concept(s) of student voice, we can begin to spin it into a thread, twisting

'fibre on fibre ....[with the]... strength of the thread not...[residing]... in the fact that some one fibre runs through its whole length, but in the overlapping of many fibres.'

(Wittgenstein, 1953, p. 32). 
Acknowledgements: With thanks to University of Wolverhampton for granting ethical approval and to all of the participants who gave so freely of their time.

Disclosure statement: There is no potential conflict of interest.

Funding: This work was supported by the University of Wolverhampton [internal funding awarded to support research project]. 


\section{References}

Arnot, M., \& Reay, D. (2007). A sociology of pedagogic voice: Power, inequality and pupil consultation. Discourse: Studies in the Cultural Politics of Education, 28, 311-325.

Bahou, L. (2011). Rethinking the challenges and possibilities of student voice and agency. Education Special Issue, 2-14.

Bakhtin, M. M. (1981). The dialogic imagination. Texas, USA: University of Texas Press. Ball, S. (2004, June). Education for sale! The commodification of everything? Proceedings of the King's Annual Education Lecture, University of London, UK. Retrieved from https://nepc.colorado.edu/sites/default/files/CERU-0410-253-OWI.pdf Bourdieu, P. (1977). Outline of a theory of practice. Cambridge: Cambridge University Press. Bourke, R., \& Loveridge, J. (2016). Beyond the official language of learning: Teachers engaging with student voice research. Teaching and Teacher Education, 57, 59-66. Bovill, C., Cook-Sather, A., \& Felten, P. (2011). Students as co-creators of teaching approaches, course design and curricula: Implications for academic developers. International Journal for Academic Development, 16(2), 133-145.

Bron, J., Bovill, C., van Vliet, E., \& Veugelers, W. (2016). Negotiating the curriculum: Realising student voice. Social Educator, 34(1), 39-54.

Bruner, J. (1977). The process of education. Cambridge, MA: Harvard University Press. Bryman, A. (2012). Social Research Methods (4 ${ }^{\text {th }}$ ed.). Oxford: Oxford University Press. Bunce, L., Baird, A., \& Jones, S. E. (2016). The student-as-consumer approach in higher education and its effects on academic performance. Studies in Higher Education, 1-20. Canning, J. (2017). Conceptualising student voice in UK higher education: Four theoretical lenses. Teaching in Higher Education, 22(5), 519-531.

Carey, P. (2013). Student engagement: Stakeholder perspectives on course representation in university governance. Studies in Higher Education, 38(9), 1290-1304. 
Charteris, J., \& Smardon, D. (2019). The politics of student voice: Unravelling the multiple discourses articulated in schools. Cambridge Journal of Education, 49(1), 93-110.

Children Act. (2004). Retrieved from

http://www.legislation.gov.uk/ukpga/2004/31/pdfs/ukpga_20040031_en.pdf

Collini, S. (2012). What are universities for? London: Penguin Books.

Cook-Sather, A. (2002). Authorizing students' perspectives: Toward trust, dialogue, and change in education. Educational Researcher, 31(4), 3-14.

Cook-Sather, A., Bovill, C., \& Felten, P. (2014). Engaging students as partners in learning and teaching: A guide for faculty. San Francisco, CA: Jossey-Bass.

Cook-Sather, A., \& Luz, A. (2015). Greater engagement in and responsibility for learning: What happens when students cross the threshold of student-faculty partnership. Higher Education Research and Development, 36(6), 1097-1109.

Czerniawski, G. (2012). Student voice-by-numbers. Research in Secondary Teacher Education, 2, 14-18.

Department for Business Innovation and Skills [BIS]. (2011). Students at the heart of the system. Retrieved from http://www.bis.gov.uk Department for Education [DfE]. (2014). Listening to and involving young people. Retrieved from

https://www.gov.uk/government/publications/listening-to-and-involving-children-and-youngpeople Department for Education and Skills [DfES]. (2001). Learning to listen: Core principles for involvement of children and young people. Retrieved from https://assets.publishing.service.gov.uk/government/uploads/system/uploads/attachment_data /file/437241/Listening to_and_involving_children_and_young_people.pdf 
Department for Education and Skills [DfES]. (2003). Every child matters. CM 5860. Norwich: HMSO.

Department for Education and Skills [DfES]. (2005). 14-19 Education and skills. CM 6476. Norwich: HMSO.

Department for Education and Skills [DfES]. (2006a). FE white paper further education: Raising skills, improving life chances. Cm 6768. Norwich: HMSO.

Department for Education and Skills [DfES]. (2006b). Personalising further education:

Developing a vision. Retrieved from https://core.ac.uk/download/pdf/4156051.pdf

Dewey, J. (1916) [1966]. Democracy and education. An introduction to the philosophy of education. New York: Free Press.

Dickerson, C., Jarvis, J., \& Stockwell, L. (2016). Staff-student collaboration: Student learning from working together to enhance educational practice in higher education. Teaching in Higher Education, 21(3), 249-265.

Douglas, J. A., Douglas, A., McClelland, R. J., \& Davies, J. (2015). Understanding student satisfaction and dissatisfaction: an interpretive study in the UK higher education context. Studies in Higher Education, 40(2), 329-349.

Education Act 2002 (UK) Retrieved from http://www.legislation.gov.uk/ukpga/2002/32/contents Fielding, M. (2006). Leadership, radical student engagement and the necessity of personcentred education. International Journal of Leadership in Education, 9, 299-313. Fielding, M. (2010). The radical potential of student voice: Creating spaces for restless encounters. The International Journal of Emotional Education, 2(1), 61-73. Retrieved from https://core.ac.uk/download/pdf/46603592.pdf

Fielding, M. (2011a). Student Voice and the Possibility of Radical Democratic Education: Re-Narrating Forgotten Histories, Developing Alternative Futures. In G. Czerniawski \& W. 
Kidd (Ed.), The Student Voice Handbook: Bridging the Academic/Practitioner Divide (pp317). London: Emerald Group Publishing Ltd.

Fielding, M. (2011b). Patterns of partnership: student voice, intergenerational learning and democratic fellowship. In N. Mockler \& J. Sachs (Ed.), Rethinking Educational Practice Through Reflexive Inquiry Essays in Honour of Susan Groundwater-Smith - Professional Learning and Development in Schools and Higher Education (pp61-75). Netherlands: Springer.

Foster Report. (2005). Realising the potential: A review of the future role of FE colleges. Retrieved from http://dera.ioe.ac.uk/5535/1/realising06.pdf Foucault, M. (1980). The eye of power. In C. Gordon (Ed.), Power/Knowledge: Selected interviews and other writing 1972-1977 (pp146-165). New York, NY: Vintage Books. Framework for Excellence. (2007). Raising standards and informing choice. Retrieved from https://webarchive.nationalarchives.gov.uk/20090602195106/http://readingroom.lsc.gov.uk/ls c/National/nat-frameworkforexellenceraisingstandards-pu-mar07.pdf

Frost, R. (2008). Developing student participation, research and leadership: The HCD student partnership. School Leadership and Management: Formerly School Organisation, 28, $353-$ 368.

Groundwater-Smith, S., \& Mockler, N. (2016). From data source to co-researchers? Tracing the shift from 'student voice' to student-teacher partnerships in educational action research. Educational Action Research, 24, 159-176.

Hall, V. J. (2015). Exploring teacher-student interactions: Communities of practice, ecological learning systems - or something else? Journal of Further and Higher Education, $1-13$. 
Hall, V. J. (2017) A tale of two narratives: student voice—what lies before us? Oxford Review of Education, 43(2), 180-193.

Hart, R. A. (1992). Children's participation: From tokenism to citizenship. Innocenti Essays No. 4: No inness 92(6). Florence: UNICEF International Child Development Centre.

Higgs, J. (2016). Practice, discourse and epistemic cultures. In J. Higgs and F. Trede (Eds.), Professional Practice Discourse Marginalia (pp. 47 - 54). Rotterdam: Sense Publishers. Hillman, N. (2014). A guide to the removal of the student number controls. HEPI Report 69: Higher Education Policy Institute. Retrieved from http://www.hepi.ac.uk/wpcontent/uploads/2014/09/Clean-copy-of-SNC-paper.pdf

Horton, M., \& Freire, P. (1990) We make the road by walking: Conversations on education and social change. Philadelphia: Temple University Press. Retrieved from http://impedagogy.com/wp/wpcontent/uploads/2016/12/Myles_Horton_Paulo_Freire_We_Make_the_Road_Chapter_4.pdf Katsifli, D. \& Green, K. (2010). Making the most of the student voice in Further Education. London: 157 group and Blackboard.

Kitcher, P. (2009). Education, democracy and capitalism. In H. Siegel (Ed.), The Oxford Handbook of Philosophy in Education (pp300 - 318). Oxford: Oxford University Press. Lensmire, T. (1998). Rewriting student voice. Journal of Curriculum Studies, 30, 261-291. Macfarlane, B. (2015). Student performativity in higher education: Converting learning as a private space into a public performance. Higher Education Research and Development, 34(2), 338-350.

Mariskind, C. (2013). Always allowing the voice: Expectations of student participation and the disciplining of teachers' practice. Teaching in Higher Education, 18(6), 596-605. Matthew, K. E., Cook-Sather, A., Acai, A., Dvorakova, S. L., Felten, P., Marquis, E., \& Mercer-Mapstone, L. (2019). Towards theories of partnership praxis: An analysis of 
interpretive framing in literature on students as partners in teaching and learning. Higher Education Research and Development, 38(2), 280-293.

McLeod, J. (2011). Student voice and the politics of listening in higher education. Critical Studies in Education, 52(2), 179-189.

Messiou, K., \& Ainscow, M. (2015). Responding to learner diversity: Student views as a catalyst for power teacher development? Teaching and Teacher Education, 51, 246-255. Mitra, D. L. (2016). Student voice research in the United States: Finding opportunities to make a difference in an era of accountability (BERA blog entry). Retrieved from https://www.bera.ac.uk/blog/student-voice-research-in-the-united-states-findingopportunities-to-make-a-difference-in-an-era-of-accountability

Nelson, E. (2015). Student Voice as Regimes of truth: Troubling authenticity. Middle Grades Review, 1(2), no page number. Retrieved from https://scholarworks.uvm.edu/mgreview/vol1/iss2/3 Nixon, E., Scullion, R., \& Hearn, R. (2018). Her majesty the student: Marketised higher education and the narcissistic (dis)satisfactions of the student consumer. Studies in Higher Education, 43(6), 927-943.

Porter, A. (2008). Hearing and responding to student voices. Brookes eJournal of Learning and Teaching, 2(3). Retrieved from http://bejlt.brookes.ac.uk/paper/the_importance_of_the_learner_voice-2/ Powney, J., \& Hall, S. (1998). Closing the loop. The Impact of Student Feedback on Students' Subsequent Learning. Scottish Council for Research in Education, Report No. 90. Retrieved from https://www.researchgate.net/publication/234775216_Closing the_Loop_The_Impact_of_St udent_Feedback_on_Students'_Subsequent_Learning_Research_Report_Series 
Quality Improvement Agency (2008). Exploring the concept of the expert learner. Retrieved from

http://www.itslifejimbutnotasweknowit.org.uk/files/libraryfrom2012/introducing_expert\%201 earner.pdf

Ramsden, P. (1998). Managing the effective university. Higher Education Research and Development, 17, 347-370.

Robinson, C., \& Taylor, C. (2013). Student voice as a contested practice: Power and participation in two student voice projects. Improving Schools, 16(1), 32-46.

Rudduck, J. (2006). The past, the papers and the project. Educational Review, 58, 131-143. Scottish Government. (2011). Putting learners at the centre - Delivering our ambitions for post-16 education. Retrieved from http://www.gov.scot/Publications/2011/09/15103949/15 Rudduck, J., \& Fielding, M. (2006). Student voice and the perils of popularity. Educational Review, 58(2), 219-231.

Seale, J., Gibson, S., Haynes, J., \& Potter, A. (2015). Power and resistance: Reflections on the rhetoric and reality of using participatory methods to promote student voice and engagement in higher education. Journal of Further and Higher Education, 39(4), 534-552. Starhawk, M. S. (1988). Truth or dare: Encounters with power, authority and mystery. San Francisco: Harper Collins.

Taylor, P. \& Sutton, K. (2016). Hearing the Marginalised Voices. In J. Higgs and F. Trede (Eds.), Professional practice discourse marginalia (pp. 189 - 196). Rotterdam: Sense Publishers.

Tedder, M., Jones, P., \& Mauger, S. (2008). How do we turn the rhetoric of 'learner voice' into reality? Adults Learning, 19(10), 24-26.

Tomlinson, M. (2017). Student perceptions of themselves as 'consumers' of higher education. British Journal of Sociology of Education, 38(4), 450-467. 
UNICEF. (1989). United Nations convention on the rights of the child. Retrieved from https://www.unicef.org.uk/what-we-do/un-convention-child-rights/

Volbers, J. (2012). Wittgenstein, Dewey, and the practical foundation of knowledge.

European Journal of Pragmatism and American Philosophy, IV(2), 1-14.

Welsh Government. (2013). Policy statement on higher education. Retrieved from

https://www.hefcw.ac.uk/documents/publications/corporate_documents/Policy\%20statement \%20on\%20higher\%20education\%20English.pdf

Wertsch, J. V. (2005). The multivoicedness of meaning. In M. S. Taylor \& S. J. Yates (Eds.), Discourse theory and practice (pp. 222-235). London: Sage Publications.

Williams, J. (2012). Consuming higher education: Why learning can't be bought. London:

Bloomsbury.

Wittgenstein, L. (2001) [1953]. Philosophical investigations. Translated by G. E. M. Anscombe. Oxford: Basil Blackwell Ltd. 